\title{
Sickle cell anemia
}

INSERM

\section{Source}

INSERM. (1999). Orphanet: an online rare disease and orphan drug data base. Sickle cell anemia. ORPHA:232

Sickle cell anemias are chronic hemolytic diseases that may induce three types of acute accidents: severe anemia, severe bacterial infections, and ischemic vasoocclusive accidents (VOA) caused by sickle-shaped red blood cells obstructing small blood vessels and capillaries. Many diverse complications can occur. 